Buca Eğitim Fakültesi Dergisi, 2021, Say1 51, s.266-286

Araştırma Makalesi
The Journal of Buca Faculty of

Education, 2021, Issue 51, p.266-286

Original Research

\title{
Code.org Platformunun 6. Sınıf Öğrencilerinin Programlama Öğrenimine Etkisi*
}

\section{The Effect of Code.org Platform on $6^{\text {th }}$ Grade Students' Learning Programming}

\author{
Ümit KARADUMAN ${ }^{1}$, Ercan AKPINAR ${ }^{2}$
}

\begin{abstract}
${ }^{1}$ Sorumlu Yazar, Bilişim Teknolojileri Öğretmeni, Türkiye, umitkaraduman90@hotmail.com, (https://orcid.org/0000-0002-5428-6548)

${ }^{2}$ Prof. Dr., Bilgisayar ve Öğretim Teknolojileri Ĕ̌̆itimi Bölümü, Buca Eğitim Fakültesi, Dokuz Eylül Üniversitesi, Türkiye, ercan.akpinar@deu.edu.tr, (https://orcid.org/0000-0002-2128-3308)
\end{abstract}

\section{ÖZ}

6. sınıf öğrencilerinin programlama öğrenimlerine Code.org platformunun etkilerinin araştırıldığı bu çalışma Milli Eğitim Bakanlığına bağlı bir ortaokulda eğitim gören öğrenciler ile yürütülmüştür. Araştırmada veri toplama aracı olarak Keçeci, Alan ve Zengin (2016) tarafindan geliştirilen Eğitsel Bilgisayar Oyunları Destekli Kodlama Öğrenimine Yönelik Tutum Ölçeği, Code.org Platformuna Yönelik Yarı Yapılandırılmış Görüşme Formu ve Programlama Öğrenim Düzeyi Belirleme Aracı kullanılmıştır. Deneysel araştırma desenine uygun olarak gerçekleştirilen araştırmada gerçek deneme modellerinden $2 \mathrm{X}$ 3'lük (deney-kontrol X ön test-son test-izleme testi) model kullanılmıştır. Görüşme formunun sonuçları içerik analizi ile betimsel olarak yorumlanmıştır. Diğer ölçme işlemlerinin sonucunda elde edilen veriler SPSS istatistik paket programı kullanılarak değerlendirilmiştir. Araştırma sonucunda öğrencilerin programlama öğrenimleri ve programlama öğrenimlerinin kalıcılıkları üzerinde Code.org platformu ile normal öğretim yöntemleri arasında Code.org platformu lehine anlamlı bir fark bulunmuştur. Ayrıca Code.org platformu, öğrencilerin eğitsel bilgisayar oyunları destekli kodlama öğrenimine karşı olan tutumlarını olumlu yönde artırmıştır. Yürütülen yarı yapılandııılmış görüşmeler sonucunda da bu platformun öğrenci başarısı üzerinde daha pozitif bir etkisi olduğu, öğrencilerin öğrenme sürecinden daha fazla memnuniyet duydukları ve Bilişim Teknolojileri ve Yazılım dersine karşı daha olumlu tutumlar geliştirdikleri ortaya konmuştur. Çalışmanın süreci ve sonuçları göz önüne alındığında; Code.org platformunun öğrenme ortamlarına bütünleştirilmesi ve bu alandaki deneysel çalışmaların kapsam olarak genişletilmesine yönelik yeni araştırmalar yapılması önerilmektedir.

Anahtar Kelimeler: Code.org, blok tabanlı programlama araçları, programlama öğrenimi.

\begin{abstract}
This study, in which the effects of the Code.org platform on the programming learning of $6^{\text {th }}$ grade students were investigated, was conducted with students studying at a secondary school affiliated with the Ministry of National Education. In this study, Attitude Scale for Educational Computer Games Supported Coding Learning developed by Keçeci, Alan and Zengin (2016), Semi-Structured Interview Form for Code.org Platform and Programming Learning Leveling Tool were used as data collecting tools. In the research carried out in accordance with the experimental research design, 2 X 3 (experimental-control X pre-test -
\end{abstract}

\footnotetext{
* Bu makale birinci yazarın ikinci yazar danışmanlığında yürüttüğü “Code.org Platformunun 6. Sınıf

Öğrencilerinin Programlama Öğrenimine Etkisi” isimli yüksek lisans tezinden üretilmiştir.
} 
post-test - retention-test) model from the real trial models was used. The results of the interview form were interpreted descriptively with the content analysis. The data obtained as a result of other measurement processes were evaluated using the SPSS statistical package program. As a result of the research, a significant difference was found between the Code.org platform and normal teaching methods in favor of the Code.org platform on the programming learning and the permanence of their programming learning. In addition, the Code.org platform positively increased the students' attitudes towards educational computer games supported coding learning. As a result of the semi-structured interviews conducted, it was revealed that this platform had a more positive effect on student achievement, students were more satisfied with the learning process and developed more positive attitudes towards the Information Technologies and Software course. Considering the process and results of the study; it is recommended to integrate the Code.org platform into learning environments and to be done new research to expand the experimental studies in this area.

Keywords: Code.org, block-based programming tools, programming learning.

\section{GİRIŞ̧}

21. yüzyılda çocukların sahip olması gereken temel beceriler arasında yaratıcılık, eleştirel düşünme, iletişim, işbirliği gibi kavramların oluğu söylenebilir. Teknolojinin sürekli ilerlemesi, eğitim sürecine kazandırdığı yenilikler ve beraberinde getirdiği kolay ulaşılabilirlik, öğrencilerin bu becerileri edinmesini oldukça kolaylaştırmaktadır. 21. yüzyıl becerilerinden biri olarak görülen ve her bireyin sahip olması gereken "Bilgi İşlemsel Düşünme (Computational Thinking)" kavramı ise 'bilgisayar bilimini kullanarak problem çözme becerisi' şeklinde tanımlanmaktadır (Wing, 2006). Bu kavrama göre algoritmik düşünme ile problemler küçük parçalara ayrılır, çözüm üretilerek sonuç gözlemlenir ve en başta ön görülen sonuca göre doğru adımlar atılmaya devam edilir. Sonuç olarak ise bu becerilere sahip olan kişiler derslerindeki ve günlük yaşantılarındaki problemlerini de kolaylıkla çözebileceklerdir (Küçükoğlu, 2014). İnsan yaşamında önemli yeri olan problem çözme süreci ise programlama eğitiminin temel parçası konumundadir.

Programlama eğitiminin, öğrencilerin problem çözme, yaratıcılık, algoritmik ve sistematik düşünme gibi birtakım düşünme becerilerini kazanmalarına etkisi olduğu farklı dönemlerde yapılan araştırmalarca belirtilerek bireyler ve kazanımlar açısından önemi her dönemde dile getirilmiştir (Çankaya, Durak ve Yünkül, 2017; Dizman, 2018; Erdem, 2018; Oluk, Korkmaz ve Oluk, 2018; Ozoran, Çağıltay ve Topall1, 2012; Özcan, Ergün, Köse, Emir ve Gezgin, 2017; Vatansever, 2018). Ancak programlama eğitiminin, amaçlanan kazanımların üzerinde önemli etkileri olduğu sürekli vurgulanırken, gerçekleştirilen programlama eğitiminin şekli, hedef kitleye ilişkin kullanılan yöntem doğrultusunda bazı sorunlar oluşturabilmektedir (Çatlak, Tekdal ve Baz, 2015). Çünkü normal yöntemlerin yer aldığı eğitim-öğretim sürecinde işin tamamlanması, geçirilen sürecin kalitesinden daha önemli görülmektedir. Öğrenmenin odak olarak görüldüğü bir ortamda ise yaşanan süreç, gözlem yapabilmek için çok önemlidir. Öğrenci bireysel öğrenme hedefleri olan, bilgi ve becerilerini geliştirmeye odaklanan ve öz değerlendirme yapabilen öğrenen konumundadır. Bu öğrenme ortamlarında öğrencilerin üstbilişlerini etkinleştirerek eleştirel ve yaratıcı düşünen, sebep-sonuç bağlantısı kurabilen, bilgi okuryazarı olan ve hayat boyu öğrenmeyi benimseyen bireyler hâline gelebilmeleri için farklı çözümler aranmaktadır (Küçükoğlu, 2014).

Cevahir ve Özdemir (2017), programlama öğreniminde, soyut düşünme becerisinde eksiklik, ezbere dayalı öğretim, tekrar ve uygulama eksikliği gibi zorluklar yaşandığını dile getirmişlerdir. Dizman (2018) ve Şimşek (2018) de çalışmalarında; metin tabanlı kodlama yapısında öğrencilerin zorluklar yaşadığını ve programlamaya karşı önyargı oluşturduklarını belirtmişlerdir. Özmen ve Altun (2014) ise çalışmalarında; pratik eksikliği, algoritma oluşturamama ve bilgi eksikliği gibi hususları programlama eğitiminde yaşanan zorluklar olarak ortaya koymuşlardır. Programlamanın öğrenciler tarafından zor ve karmaşık olarak görülmesi, onların programlamaya ilişkin tutumlarını da olumsuz olarak etkileyebilmektedir. Ayrıca bu 
durum, öğrencilerde başarısızlık hissi de oluşturabilmektedir. Bu olumsuzlukların üstesinden gelmek için programlama eğitimini kolaylaştırabilmek, yaşanabilecek kaygı ve stresi azaltabilmek, derse katılımı arttırabilmek için, büyük firmaların geliştirdiği blok tabanlı görsel programlama araçları kullanılabilir (Demir, 2015; Genç ve Karakuş, 2011; Ozoran ve diğerleri, 2012). Aytekin, Çakır, Yücel ve Kulaözü (2018); araştırılan açık kaynaklar ve alanyazın irdelendiğinde birçok temel yetinin kazanılması için programlama derslerinde blok tabanlı görsel programlama araçlarından yararlanılabileceğini, bu sayede geleneksel programlama dillerinin öğrenilmesindeki zorlukların aşılabileceğini ve mevcut oyunlaştırmanın öğrencilerin motivasyonlarına, yeni fikirler ve projeler geliştirmelerine katkı sağlayabileceğini ifade etmişlerdir. Oyunlaştırma süreci, oyun karakteristikleri ile bütünleştirerek, öğrencilerin mevcut öğrenme alanında öğrenmesini kolaylaştırma potansiyelinden faydalanmaktır. Oyunlaştırma; oyun olmayan sistemlerde, kullanıcı deneyimini artırmak ya da kullanıcinın ortama bağlanmasını sağlamak amacıyla video oyun bileşenlerinin kullanılmasıdır (Karataş, 2014). Buna paralel olarak Code.org, Alice, Kodu ve Scratch gibi programlama öğrenmeyi kolaylaştıran araçların seçilmesi ve bu sayede öğrenme ortamının eğlenceli hâle getirilmesi, ögrrencilerin tutumlarını da olumlu yönde etkileyebilir. Nitekim Yıldız (2018) ve Patan (2016) da gerçekleştirdiği çalışmalarında; Code.org platformu kullanımının öğrencilerin tutumunu olumlu yönde etkilediği sonucuna ulaşmışlardır.

Code.org, Alice, Kodu ve Scratch gibi blok tabanlı görsel programlama araçları ile programlamanın öğretim amaçlı olarak kullanımı yaygınlaşmıştır. Bu ortamlar, erken yaştaki öğrencilerin geleneksel programlama dillerinin kompleks kod yapılarını öğrenme şartını ortadan kaldırarak, uygulamalar oluşturabilmelerini sağlamaktadır (Resnick ve diğerleri, 2009). Ayrıca görsel programlama ortamları çocuklara yönelik tasarlandıkları için onların gelişim seviyelerine uygun durumdadır (Fessakis, Gouli ve Mavroudi, 2013). Bir öğrenme materyalinin, gerçeklik, açık uçlu tasarım görevlerindeki zorlukların dengesi, zengin ve çeşitli geri bildirimler, tartışma ve işbirliği, çoklu bağlamlar, deneyler ve araştırmalar gibi öğelere sahip olması beklenmektedir; öğrenciye verilecek tasarım görevlerinin de eğitsel yazılımlar, eğitsel oyunlar, web siteleri veya PowerPoint sunuları şeklinde olması etkililiği artırabilmektedir (Erekmekçi ve Fidan, 2012). Erasmus Von Rotterdam "Öğretim işi, çocuklar için zevkli bir şekle sokulmalıdır. Bu nedenle öğretim, oyun ile birleştirilmelidir.” sözü ile çocuklara verilen eğitimin oyunlaştırılmasının önemine vurgu yapmıştır (Bozan, 2014). Ayrıca eğitim ile oyun iç içe bulundurularak hem yeni kavramlar öğrenciye öğretilebilir hem de bu kavramların kalıcılı̆̆ 1 sağlanabilir (Kılınçpınar, 2014). Nitekim Savaş (2014), Yıldırım (2015) ve Koka (2018) da gerçekleştirdiği çalışmalarında; oyun öğesinin öğrenci başarısı ve kalıcılığı üzerinde olumlu etkisi olduğunu ifade etmişlerdir. Ayrıca Savaş (2014), öğretim esnasında kullanılan eğitsel oyunlar sayesinde öğrencilerin oynayarak öğrenebildiklerini, dersi ve ilgili öğretmenlerini daha çok sevdiklerini dile getirmiştir.

Görsel programlama ortamları öğrencilerin kendi etkileşimli oyunlarını, animasyonlarını, benzetim uygulamalarını ve hikâyelerini yaratmaya olanak tanıyan görsel programlama araçlarıdır ve öğrencilere bazı matematiksel düşüncelerini animasyon hâline dönüştürerek yeni şeyler oluşturmalarını mümkün kılan sanal ortamlar sağlamaktadırlar (Taylor, Harlow ve Forret, 2010). Bu öğrenme ortamlardaki başlıca hedef farklı becerileri geliştirerek öğrenme çıktılarını ve öğrencilerin motivasyonunu artırmaktır (Sayın ve Seferoğlu, 2016). Bu araştırmada oyunlaştırılmış blok tabanlı görsel programlama araçları içerisinden Code.org platformu seçilmiş ve bu platformun etkinliği incelenmiştir. Code.org platformunun, ticari kayg1 taşımaması, her yerde her zaman öğrenme olanăgı tanıması, sürükle-bırak yöntemiyle kolaylık sunması, yapılan işlemlerin kod karşılığının görüntülenebilmesi, eğlenceli ve etkileşimli yapısı, öğretmen-öğrenci kullanımı ile okul yapısına uyması gibi özellikleri bu seçimi belirleyen nedenlerden bazılarıdır. Ayrıca örgün eğitimine devam eden genç ve çocukların eğlenerek öğrenmeleri için geçmişte popüler olmuş uygulamaların kullanılmasının faydalı olabileceği (Taşdemir ve Şüyun, 2016) düşünüldüğünde; Angry Birds, Flappy, Minecraft gibi oyunlar1 içerisinde barındıran Code.org platformu öğrenciler tarafından ilgi çekici görülmektedir. 
Yapılan alanyazın taraması ve analizler, programlama eğitimine yönelik gerçekleştirilen akademik çalışmaların çok az sayıda olduğunu gösterirken birçok ülkenin eğitim müfredatlarına programlama eğitimini dâhil ettiğini veya buna yönelik hazırlıklar yaptığını da ifade etmektedir (Sayın ve Seferoğlu, 2016). Programlama dilleri öğretimi, çeşitli ülkeler tarafından (İngiltere, ABD, Güney Kore, Fransa, Avusturya, Bulgaristan, İspanya, Çek Cumhuriyeti, Tayvan, Danimarka, Finlandiya, Macaristan, İrlanda, Avustralya, Litvanya, Malta, İsrail, Polonya, Estonya, Portekiz, Slovakya) öğretim programlarına dâhil edilerek zorunlu statüde okutulan bir ders konumundadır (Demirer ve Sak, 2016; Sayın ve Seferoğlu, 2016). Programlama eğitimi sadece okullarda ders olarak okutulmanın dışında "Hour of Code (Kod Saati)", "Europe CodeWeek (Avrupa Kod Haftası)" gibi çeşitli etkinlik ve organizasyonlarla dünya genelinde tanıtılarak yaygınlaştırılmaya ve sevdirilmeye çalışılmaktadır. Ayrıca Code.org gibi kâr amacı gütmeyen kuruluşlarla, büyük olarak addedilen firmaların işbirliği yaptığı bilinmekte ve bu çalışmaların geleceğin yetişmiş insan gücünü oluşturabileceği düşüncesiyle politika yapıcılar ve uygulayıcılar tarafından da desteklendiği anlaşılmaktadır. Bahsedilen bu faktörler de araştırma konusunun seçiminde etkili olan unsurlardandır.

\subsection{Araştırmanın Amacı ve Önemi}

Günümüzde okuma-yazma bilen, aritmetik bilgileri olan kişilere ithafen kullanılan eğitimli insan ifadesi yaşanan hızlı değişimlerden etkilenmiştir. Eğitimin hedeflediği temel becerilere; dijital kültürün ortak dili olan, öğrencilerin kendi geleceklerini planlamaları imkânını sunan kodlama becerisi de eklenmiştir (EBA, 2019). Türk Eğitim sisteminin temel amacı olarak Onuncu Kalkınma Planında "düşünebilme, algılayabilme, sorun çözebilme yeteneği gelişmiş, bilimi ve teknolojiyi kullanabilen ve teknoloji üretimine yatkın, bilgi toplumları için gerekli temel bilgi ve becerilere sahip, üretebilen bireyler" ifadeleri yer almaktadır (Onuncu Kalkınma Planı, 2014). İçinde bulunduğumuz bilgi çağında kodlama eğitimi, bu hedef doğrultusunda önemli bir araçtır (Aytekin ve diğerleri, 2018). Erken yaştan itibaren bu konuda öğrencilere imkân sunulması çok önemli hâle gelmiştir. Dolayısıyla temel eğitim seviyesinde gerekli öğrenme araçlarının hazırlanması önemli bir eksikliği giderecek, programlama öğretimi için de sağlam bir destek ayağı sağlanmış olacaktır (Akpınar ve Altun, 2014).

Endüstrileşen ülkeler, yeni sanayi devrimi konumundaki Endüstri 4.0'a daha hazır ve etkin bir şekilde geçmek için programlama öğrenmenin gerekliliği görüşünü benimsemiş (Aytekin ve diğerleri, 2018) ve bu alana yönelik zorunlu derslere öğretim programlarında yer vermiştir (Demirer ve Sak, 2016; Sayın ve Seferoğlu, 2016). Gerekli olmasının yanı sıra öğreniminin de zor bir süreç olduğu belirtilen programlamanın daha iyi öğretilebilmesi amacıyla görsel programlama araçlarının kullanılması gerekliliği ifade edilmiş ancak ülkemizde yeterli seviyede kullanılmadığ fark edilmiştir (Solmaz, 2014). Öğrencilere senaryo tasarlayabilecekleri bir imkân sunup, özgür bir ortam sağlayıp, animasyonlarla bu sürecin somutlaştırılmasını (Ramadhan, 2000), böylece daha ilgi çekici bir ortama dönüşmesini (Utting, Cooper, Kölling, Maloney ve Resnick, 2010) sağlayan bu araçlar, öğrencileri kodları ve kuralları ezberlemekten, söz dizimi yanlışlarından ve kod satırlarına boğulmaktan kurtarmıştır.

Blok tabanlı görsel programlama araçlarından olan Code.org platformu; Microsoft, Facebook, Twitter, Google gibi alanlarında dünyanın en meşhur programcıları ve büyük teknoloji firmalarının kurucularının yer aldığı kişilerin destekleriyle programlama öğreniminin yaygınlaşması için başlatılan proje kapsamında kurulmuştur. Bu platform sahip olduğu yap1 sebebiyle eğitim faaliyetleri için uygun durumda bulunmakta, öğretmen ve öğrenci kullanımlarına müsait olması okul yapısıyla benzerlik taşımaktadır. Süreç içerisinde öğretmen öğrencileri sistem üzerinden takip edebilmekte, ilgili kursa ilişkin gerekli gördüğü müdahaleleri yapabilmektedir. Öğretmenin yanı sıra öğrenciler de kendi ilerlemelerini izleyebilmekte böylece zaman ve mekan kolaylığı sağlamaktadır.

Alanyazındaki Code.org platformunun öğrencilerin programlama öğrenim düzeylerine ve tutumlarına etkisini içeren çalışmaların eksikliği dikkate alındığında, konu üzerinde çalışmak 
isteyen araştırmacılar için bu çalışmanın kaynak çeşitliği sağlayacağı düşünülmektedir. Ayrıca programlama konusunun öğretimine ilişkin; Code.org platformunun sahip olduğu özelliklerle birlikte Bilişim Teknolojileri ve Yazılım (BTY) dersi programlama öğretimi konusunda eğiticilere kılavuzluk ederek öğretime yardımcı olması beklenmektedir. Programlama öğretimine duyulan ihtiyaç ve Code.org platformunun özellikleri dikkate alındığında, programlama öğretimine yönelik ilgili platformun çözüm getirebileceği değerlendirilerek bu araştırmanın amacı, Code.org platformunun ortaokul 6. sınıf öğrencilerinin programlamaya ilişkin tutumlarına ve programlama öğrenimlerine olan etkilerini araştırmak ve öğrencilerin bu platforma yönelik görüşlerini incelemek olarak belirlenmiştir.

\subsection{Araştırmanın Problemi ve Alt Problemler}

Çalışmanın problemi "Code.org platformu ile programlama öğreniminin 6. sınıf öğrencilerinin eğitsel bilgisayar oyunları destekli kodlama öğrenimlerine yönelik tutumlarına, programlama öğrenim düzeylerine, programlama öğrenimlerinin kalıcılık düzeylerine etkisi nedir ve deney grubu öğrencilerinin platforma yönelik görüşleri nelerdir?" olarak belirlenmiştir. Buna bağlı olarak çalışmanın alt problemleri aşağıda ifade edilmiştir.

1. Code.org platformunun deney ve kontrol grubunda yer alan öğrencilerin programlama öğrenim düzeylerine etkisi nedir?

2. Code.org platformunun deney ve kontrol grubunda yer alan öğrencilerin programlama öğrenimlerinin kalıcılık düzeylerine etkisi nedir?

3. Code.org platformunun deney ve kontrol grubunda yer alan öğrencilerin eğitsel bilgisayar oyunları destekli kodlama öğrenimlerine yönelik tutumlarına etkisi nedir?

4. Deney gurubu öğrencilerinin Code.org platformuna yönelik görüşleri nelerdir?

\section{YÖNTEM}

\subsection{Araştırma Modeli, Değişkenler ve Deneysel Desen}

Çalışma kapsamında gerçek deneme modellerinden "ön test - son test kontrol gruplu desen" kullanılmıştır. Alınan etik kurulu izninin ardından öğrenciler, rastgele olarak gruplara yerleştirilmiş, gruplardan biri kontrol, diğeri deney grubu olarak isimlendirilmiştir. Araştırma süresince haftalık iki ders saati olarak yürütülen 6 . sınıf BTY dersi öğretim programı içerisindeki "Problem Çözme ve Programlama" ünitesi; deney grubuna Code.org platformu kullanılarak, kontrol grubuna ise normal öğretim yöntemleri (Anlatım, soru-cevap, tartışma, problem çözme, görüş geliştirme, gösterip yaptırma) kullanılarak işlenmiştir.

$\mathrm{Bu}$ araştırmada "Code.org platformu ile programlama öğretimi" ve "Normal öğretim yöntemleri ile programlama öğretimi" olmak üzere iki bağımsız değişken, öğrencilerin "Programlama Öğrenim Düzeyleri”, "Programlama Öğrenimlerinin Kalıcılık Düzeyleri" ve "Eğitsel Bilgisayar Oyunları Destekli Kodlama Öğrenimine Yönelik Tutumları" olmak üzere 3 bağımlı değişken bulunmaktadır. Ön test - son test kontrol gruplu desen Tablo 1'de verildiği gibi gösterilmiştir.

Tablo 1. Deneysel İşlem Düzeni

\begin{tabular}{|c|c|c|c|c|}
\hline Gruplar & Ölçme & İşlem & Ölçme & İzleme \\
\hline $\begin{array}{l}\text { Deney Grubu } \\
\text { (DG) }\end{array}$ & $\begin{array}{l}\text { EBODKÖYTÖ } \\
\text { PÖDA }\end{array}$ & $\begin{array}{l}\text { Code.org Platformu ile } \\
\text { Programlama Öğretimi }\end{array}$ & $\begin{array}{l}\text { EBODKÖYTÖ } \\
\text { PÖDA } \\
\text { CPGF }\end{array}$ & PÖDA \\
\hline $\begin{array}{l}\text { Kontrol Grubu } \\
\text { (KG) }\end{array}$ & $\begin{array}{l}\text { EBODKÖYTÖ } \\
\text { PÖDA }\end{array}$ & $\begin{array}{l}\text { Normal Yöntemler ile } \\
\text { Programlama Öğretimi }\end{array}$ & $\begin{array}{l}\text { EBODKÖYTC } \\
\text { PÖDA }\end{array}$ & PÖDA \\
\hline
\end{tabular}

* CPGF: Code.org Platformuna Yönelik Yarı Yapılandırılmış Görüşme Formu

* PÖDA: Programlama Öğrenim Düzeyi Belirleme Aracı

* EBODKÖYTÖ: Eğitsel Bilgisayar Oyunları Destekli Kodlama Öğrenimine Yönelik Tutum Ölçeği 


\subsection{Araştırma Grubu}

$\mathrm{Bu}$ araştırmada deneysel desen kullanıldığından evren ve örneklem yerine çalışma grubu hakkında bilgi verilmesi daha uygun görülmektedir. Araştırmanın çalışma grubunu 2016-2017 öğretim yılının ikinci döneminde, Kütahya ili Gediz ilçesi Altınkent Ortaokulunda öğrenim gören 22 altıncı sınıf öğrencisi oluşturmaktadır. Gerçek deneme modeli çerçevesinde rastgele olarak deney ve kontrol grupları belirlenmiştir. Deney grubu 8'i erkek, 3'ü kız olmak üzere toplam 11 öğrenciden; kontrol grubu ise 4'ü kız, 7'si erkek olmak üzere toplam 11 öğrenciden oluşmaktadır.

Elde edilen verilere dayalı olarak Mann Whitney U testi sonuçlarına bakıldığında deney ve kontrol grubu öğrencilerinin ön test olarak uygulanan EBODKÖYTÖ puan ortalamaları arasında $(\mathrm{U}=56.500, \mathrm{p}>.05)$ ve ön test olarak uygulanan PÖDA ölçeği puanları arasında $(\mathrm{U}=54.500, \mathrm{p}>.05)$ .05 düzeyinde anlamlı bir fark bulunamamıştır. Code.org platformunun kullanıldığı deney grubu öğrencileri ile normal öğretim yönteminin uygulandığı kontrol grubu öğrencilerinin EBODKÖY tutumları ve programlama öğrenim düzeyleri arasında anlamlı farklılık bulunmaması alt problemlerin yorumlanması açısından önemlidir.

\subsection{Veri Toplama Araçları, Verilerin Toplanması ve Analizi}

\subsubsection{Eğitsel bilgisayar oyunları destekli kodlama öğrenimine yönelik tutum ölçeği (EBODKÖYTÖ)}

EBODKÖYTÖ, Keçeci ve diğerleri (2016) tarafından geliştirilmiştir. Çalışmalar sonucunda 22 olumlu 6 olumsuz maddeden oluşan 28 maddelik veri toplama arac1 oluşturulmuştur. Likert tipteki bu ölçeğin KMO değeri .840, kikare değeri anlamlı $\left(\mathrm{x}^{2}{ }_{(630)}=3087.798 ; \mathrm{p}=.<.01\right)$, güvenirlik katsayıs1 .833 olarak tespit edilmiştir. EBODKÖYTÖ ölçme aracında katılımcıların cinsiyetlerinin, yaşlarının ve sınıf düzeylerinin sorulduğu maddeler de bulunmaktadır.

EBODKÖYTÖ, deney ve kontrol grubunda yer alan öğrencilerin uygulama öncesi ve sonrası tutum seviyelerini tespit etmek amaciyla, gerçekleştirilecek öğretimden önce (Şubat 2017) ve sonra (Nisan 2017) olmak üzere iki defa sınıf ortamında uygulanmıştır. Elde edilen anketlerin sonuçları SPSS programına aktarılmıştır. Bu çalışma içerisinde öğrenciler tarafından boş bırakılan, iki veya daha fazla seçeneğin ya da "Kararsızım" seçeneğinin işaretlendiği maddelere üç puan verilmiştir. Üç puan ölçek çerçevesinde SPSS programına kayıp değer olarak işlenmiştir. Bir puan negatif uçtaki tutumu, beş puan pozitif uçtaki tutumu temsil etmektedir. EBODKÖYTÖ verilerinin çözümlenmesi sürecinde parametrik olmayan testlerden (Mann-Whitney U testi, Wilcoxon işaretli sıra sayıları testi) faydalanılmıştır. Analizlerde ölçüm sonuçları arasındaki farkın anlamlılığ 1.05 düzeyinde değerlendirilmiştir.

\subsubsection{Programlama Öğrenim Düzeyi Belirleme Aracı (PÖDA)}

PÖDA öğrencilerin grup içi ve gruplar arası programlama öğrenim düzeyleri arasında anlamlı bir farklılık olup olmadığını belirlemek amacıyla hazırlanmıştır. PÖDA içerisinde programlama öğrenimine yönelik tarama soruları da yer almaktadır. Var olan kazanımlara yönelik olarak hazırlanan ölçme aracı Çanakkale ve Kocaeli illerindeki iki ortaokulda yapılan pilot uygulamalar sonrası uzman görüşleri alınarak revize edilmiştir. Tekrar pilot uygulamaya tabi tutularak uzman görüşleri alınmış, 10 soru ve yanıtları şeklinde hazır hâle getirilmiştir.

PÖDA, deney ve kontrol grubunda yer alan öğrencilerin programlama öğrenim düzeylerini belirlemek amaciyla, ön test (Şubat 2017), son test (Nisan 2017) ve öğrencilerin bilgilerinin kalıcılığını belirlemek için son testten beş hafta sonra izleme testi (Mayıs 2017) olmak üzere üç defa sınıf ortamında uygulanmıştır. PÖDA verilerinin çözümlenmesi sürecinde de kovaryans analizi, ikili karşılaştırmalar testi, betimsel istatistikler ve parametrik olmayan testlerden (ANCOVA, Bonferroni, Mann-Whitney $U$ testi, Wilcoxon işaretli sıra sayıları testi) 
faydalanılmıştır. PÖDA kapsamında öğrencilerin açık uçlu sorulara verdiği yanıtlardan oluşan veriler üç ayrı alan uzmanı tarafindan pilot çalışma sürecinde oluşturulan cevap anahtarına göre $(10 \times 10=100$ puan) değerlendirilmiş, ulaşılan sonuçların ortalamaları alınarak elde edilen veriler SPSS yazılımına girilmiştir. Analizlerde ölçüm sonuçları arasındaki farkın anlamlılığı 05 düzeyinde değerlendirilmiştir.

\subsubsection{Code.org Platformuna Yönelik Yarı Yapılandırılmış Görüşme Formu (CPGF)}

Çalışmanın amacı doğrultusunda, uzman görüşü alınarak araştırmacı tarafından CPGF hazırlanmıştır. Bu veri toplama aracının hazırlanma aşamasında Çanakkale ve Kocaeli illerindeki iki ortaokulda öğrenim gören öğrenciler ile pilot uygulama gerçekleștirilmiștir. Pilot uygulamanın ardından, ölçeğin kapsam geçerliğinin sağlanması ve daha anlaşılır hâle getirilmesine yönelik uzman görüşleri alınarak görüşme formu hazırlık süreci tamamlanmıştır. Son hâliyle 10 sorudan oluşan görüşme formu, deney grubu öğrencilerinin deneysel işlem sonrasında Code.org platformuna yönelik görüşlerini tespit etmek amacıyla uygulamaya hazır hâle gelmiştir.

Deney grubunda yer alan 11 öğrencini CPGF veri toplama aracında yer alan sorulara verdikleri yanıtlar 2017 yılı Nisan ayında ses kayıt aracıyla kaydedilmiştir. Görüşme süresi ortalama 8 dakika 53 saniye sürmüştür. Kayıt altına alınan görüşmelerden, bir alan uzmanıyla paralel olarak yazılı dökümler oluşturulmuş ve karşılaştırma yapılarak elde edilen verilerin güvenirliği sağlanmıştır. CPGF ölçme araçlarından toplanan verilerin çözümlenmesinde içerik analizinden faydalanılmıştır. Araştırmada görüşme formunda yer verilen sorular birer tema olarak kabul edilmiş ve görüşmeye katılan deney grubu öğrencilerinin bu sorulara verdikleri cevaplardan kategoriler oluşturularak sunulmuştur. Görüşme yapılan öğrencilerin görüşlerine yönelik doğrudan alıntılara da yer verilmiştir. Ayrıca, kategorilerin hangi sıklıkta tekrar ettiği belirlenmiş ve tablo hâline getirilerek sunulmuştur. CPGF ölçme araçlarından elde edilen veriler; birbirinden bağımsız iki uzman kişi tarafından ayrı ayrı kodlanmış ve güvenirliği tespit etmek amacıyla kodlayıcılar arası uyum yüzdesi $(\mathrm{P}=\% 90,91)$ hesaplanmıştır.

\section{BULGULAR}

\subsection{Code.org Platformunun 6. Sınıf Öğrencilerinin Programlama Öğrenim Düzeylerine Etkisi}

Tablo 2'deki Mann Whitney U testi sonuçları dikkate alındığında ön test sonuçları arasında anlamlı farklılık bulunmayan deney ve kontrol grubu öğrencilerinin son test olarak uygulanan PÖDA ölçeği puanları arasında .05 düzeyinde deney grubu lehine anlamlı bir fark bulunmuştur $(\mathrm{U}=28.000, \mathrm{p}<.05)$.

Tablo 2. PÖDA son test uygulama sonuçlarının gruplara göre $U$ testi sonuçları

\begin{tabular}{lllllll}
\hline Grup & $\mathbf{N}$ & Sira Ortalamasi & Sira Toplamı & $\mathbf{U}$ & $\mathbf{z}$ & $\mathbf{p}$ \\
\hline Kontrol & 11 & 8.55 & 94.00 & 28.000 & -2.14 & .032 \\
Deney & 11 & 14.45 & 159.00 & & & \\
Toplam & 22 & & & & & \\
\hline
\end{tabular}

Tablo 3'e göre yapılan Wilcoxon İşaretli Sıralar testi sonuçları dikkate alınarak kontrol grubunda yer alan öğrencilerin ön test ve son test PÖDA ölçeği puanları arasında .05 düzeyi baz alınarak son test lehine anlamlı bir fark bulunmuştur $(\mathrm{p}<.05)$.

Tablo 3. KG ön test ve son test PÖDA sonuçlarının karşılaştırılması

\begin{tabular}{cccccc}
\hline Ön Test-Son Test & $\mathbf{n}$ & Sira Ortalaması & Sira Toplamı & $\mathbf{z}$ & $\mathbf{p}$ \\
\hline Azalma & 0 & .00 & .00 & $-2.934^{*}$ & \multirow{2}{*}{.003} \\
Artma & 11 & 6.00 & 66.00 & &
\end{tabular}


Eşit

0

*Negatif sıralar temeline dayalı

Tablo 4'e göre yapılan Wilcoxon İşaretli Sıralar testi sonuçlarına bakıldığında deney grubunda yer alan öğrencilerin ön test ve son test PÖDA ölçeği puanları arasında .05 düzeyi baz alınarak son test lehine anlamlı bir fark bulunmuştur $(\mathrm{p}<.05)$.

Tablo 4. DG ön test ve son test PÖDA sonuçlarının karşılaştırılması

\begin{tabular}{cccccc}
\hline Ön Test-Son Test & $\mathbf{n}$ & Sıra Ortalaması & Sıra Toplamı & $\mathbf{z}$ & $\mathbf{p}$ \\
\hline Azalma & 0 & .00 & .00 & & \\
Artma & 11 & 6.00 & 66.00 & $-2.936^{*}$ & .003 \\
Eşit & 0 & - & - & & \\
\hline
\end{tabular}

*Negatif siralar temeline dayalı

\subsection{Code.org Platformunun 6. Sınıf Öğrencilerinin Programlama Öğrenimlerinin Kalıcılık Düzeylerine Etkisi}

DG ve KG arasında PÖDA son test puanları kontrol altına alındığında izleme testi puanları açısından gruplar arasında istatistiksel olarak anlamlı fark olup olmadığını belirlemek için, son testin uygulanmasından 5 hafta sonra izleme testi uygulanmıştır. Deney ve kontrol gruplarındaki öğrencilerin PÖDA sontest ve izleme testi puanlarının istatistiki verileri Tablo 5'te sunulmuştur.

Tablo 5. KG ve DG son test-izleme testi PÖDA verileri

\begin{tabular}{|c|c|c|c|c|c|}
\hline \multicolumn{2}{|l|}{ Gruplar N } & \multicolumn{2}{|c|}{ Toplam Puanlar } & \multicolumn{2}{|c|}{$\begin{array}{l}\text { Düzeltilmiş } \\
\text { Ortalamalar }\end{array}$} \\
\hline & & $\overline{\mathbf{X}}$ & SS & $\overline{\mathbf{X}}$ & SH \\
\hline \multirow{2}{*}{ Deney 1} & Son test & 62.91 & 14.29 & & \\
\hline & İzleme testi & 63.18 & 19.12 & 63.51 & 5.06 \\
\hline \multirow{2}{*}{ Kontrol 11} & Son test & 49.27 & 12.07 & & \\
\hline & İzleme testi & 41.27 & 10.07 & 40.95 & 5.06 \\
\hline
\end{tabular}

Kovaryans analizi sonuçları, son test toplam puanları kontrol altına alındığında, grupların düzeltilmiş izleme testi toplam puanları açısından anlamlı derecede farklılaştığını göstermiştir. Farklılaşmanın hangi grup lehine olduğunu istatistiksel olarak belirlemek için Bonferroni ikili karşılaştırmalar testi yapılmış, deney grubu lehine anlamlı farklılık tespit edilmiştir $(p=.008<.05)$ (Tablo 6).

Tablo 6. PÖDA verileri DG ve KG izleme testi PÖDA sonuçlarının karşılaştırılması

\begin{tabular}{ccccc}
\hline Gruplar & $\begin{array}{c}\text { Ort. Farklar } \\
\text { (DG-KG) }\end{array}$ & Std. Hata & $\boldsymbol{p}$ & Bonferroni \\
\hline DG KG & 22.555 & 7.595 & .008 & DG $>$ KG \\
\hline
\end{tabular}

\subsection{Code.org Platformunun Deney ve Kontrol Grubunda Yer Alan Öğrencilerin EBODKÖY Tutumlarına Etkisi}

Tablo 7'deki Mann Whitney U testi sonuçları doğrultusunda ön test sonuçları arasında anlamlı farklılık bulunmayan deney ve kontrol grubu ögrencilerinin son test olarak uygulanan EBODKÖYTÖ puanları arasında .05 düzeyinde deney grubu lehine anlamlı bir fark bulunmuştur $(\mathrm{U}=30.000, \mathrm{p}<.05)$.

Tablo 7. EBODKÖYTÖ son test uygulama sonuçlarının gruplara göre $U$ testi sonuçları

\begin{tabular}{lllllll}
\hline Grup & N & Sira Ortalaması & Sira Toplamı & U & z & p \\
\hline
\end{tabular}




\begin{tabular}{lllllll}
\hline Kontrol & 11 & 8.73 & 96.00 & 30.000 & -2.004 & .045 \\
Deney & 11 & 14.27 & 157.00 & & & \\
Toplam & 22 & & & & & \\
\hline
\end{tabular}

Tablo 8'e göre yapılan Wilcoxon İşaretli Sıralar testi sonuçlarına bakıldığında kontrol grubunda yer alan öğrencilerin ön test ve son test EBODKÖYTÖ puanları arasında .05 düzeyinde anlamlı bir farkın oluşmadığ görülmektedir ( $\mathrm{p}>.05)$.

Tablo 8. KG ön test ve son test EBODKÖYTÖ sonuçlarının karşılaştırılması

\begin{tabular}{cccccc}
\hline Ön Test-Son Test & n & Sıra Ortalaması & Sıra Toplamı & z & p \\
\hline Azalma & 5 & 6.40 & 32.00 & & \\
Artma & 6 & 5.67 & 34.00 & $-.089^{*}$ & .929 \\
Eşit & 0 & - & - & & \\
\hline
\end{tabular}

*Negatif sıralar temeline dayalı

Tablo 9'a göre yapılan Wilcoxon İşaretli Sıralar testi sonuçları doğrultusunda deney grubunda yer alan öğrencilerin ön test ve son test EBODKÖYTÖ puanları arasında .05 düzeyi baz alınarak son test lehine anlamlı bir fark bulunmuştur $(\mathrm{p}<.05)$.

Tablo 9. DG ön test ve son test EBODKÖYTÖ sonuçlarının karşılaştırılması

\begin{tabular}{cccccc}
\hline Ön Test-Son Test & $\mathbf{n}$ & Sıra Ortalaması & Sıra Toplamı & $\mathbf{z}$ & $\mathbf{p}$ \\
\hline Azalma & 1 & 2.00 & 2.00 & & \\
Artma & 9 & 5.89 & 53.00 & $-2.599^{*}$ & .009 \\
Eşit & 1 & - & - & & \\
\hline
\end{tabular}

*Negatif sıralar temeline dayalı

\subsection{Deney Gurubu Öğrencilerinin Code.org Platformuna Yönelik Görüşleri}

"Deney gurubu öğrencilerinin Code.org platformuna yönelik görüşleri nasıldır?” problem cümlesine cevap aramak amacıyla, deney grubu öğrencileriyle yapılan yarı yapılandırılmış görüşme ölçeğine verdikleri cevaplar kategorize edilmiş ve bu kategorilere ait frekans değerleri sırayla verilmiştir.

Tablo 10. “Code.org platformunun kodlamayı öğrenmen üzerinde (Akış Şeması, Döngüler, Koşul Yapıları vb.) etkili olduğunu düşünüyor musun? Etkili ise hangi yönlerden etkili oldu? $\mathrm{Ne}$ kazandırdı?"

\begin{tabular}{lll}
\hline Kategoriler & f & Örnek Alıntılar \\
\hline Eğlenceli & 9 & $\begin{array}{l}\text { Ö5 Daha ĕ̆lenceli, oyun gibi kullandık. } \\
\text { Ö6 Daha iyi, etkili, güzel ögrenebildik. }\end{array}$ \\
\hline Uygulamalı & 8 & $\begin{array}{l}\text { Ö4 Yaparak, görerek ögrenebildik. } \\
\text { Ö1 Kendi oluşturduğumuz oyunları oynayabiliriz. }\end{array}$ \\
\hline Öğrenmeyi kolaylaştırıcı & 8 & $\begin{array}{l}\text { Ö10 Aşamalı şekilde kolaydan zora ilerledik. } \\
\text { Ö9 Daha hızll öğrenebildik. } \\
\text { Ö3 Öğretimi kolaylaştırdl. }\end{array}$ \\
\hline
\end{tabular}

*Bir öğrencinin birden fazla görüşü yer alabilmektedir.

Tablo 11. "Code.org platformunu kullanmanın kodlamayı daha kalıcı olarak öğrenmene etki edeceğini düşünüyor musun? Açıklayabilir misin?"

\begin{tabular}{lll}
\hline Kategoriler & $\boldsymbol{f}$ & Örnek Alıntılar \\
\hline Uygulamalı & 8 & Ö4 Çünkü görerek ve yaparak ögrenebildim. \\
\hline Eğlenceli & 6 & $\begin{array}{l}\text { Ö8 Çünkü oyun oynar gibi öğrenebildim. } \\
\text { Ö1 Çünkü eğlenceliydi. }\end{array}$ \\
\hline
\end{tabular}




\begin{tabular}{|c|c|c|}
\hline Esnek öğrenme ortamı & 1 & $\begin{array}{l}\text { Ö9 Çünkü hem okulda hem evde her zaman } \\
\text { kullanabiliyoruz. }\end{array}$ \\
\hline \multicolumn{3}{|c|}{$\begin{array}{l}\text { *Evet }(f=11) \text {. } \\
\text { *Bir ögrencinin birden fazla görüşü yer alabilmektedir. } \\
\text { Tablo 12. "Code.org platformunun en beğendiğin tarafları nelerdi? Açıklar mısın?" }\end{array}$} \\
\hline Kategoriler & $f$ & Örnek Alıntılar \\
\hline Eğlenceli & & $\begin{array}{l}\text { Ö3 Oyun oynar gibi kullanabiliyorduk. } \\
\text { Ö7 Bölümler (Çiftçi, Angry Birds vb.) güzeldi. } \\
\text { Ö2 Çeşitli bölümler vardl. } \\
\text { Ö6 Eğlenceliydi. }\end{array}$ \\
\hline Uygulamal1 & 6 & Ö1 Kendi hesabımızla oturum açıp kullanıyorduk. \\
\hline Yönlendirici & & $\begin{array}{l}\text { Ö5 İlerleme durumumuzu, tamamlanan, yartm kalan, } \\
\text { yapılmamış bölümlerimizi renkli olarak takip ediyorduk. } \\
\text { Ö9 Bölümlerden önce bilgilendirici videolar vardl. }\end{array}$ \\
\hline Öğrenmeyi kolaylaştırıcı & 2 & Ö10 Aşamalı olarak kolaydan zora doğru gidiyordu bölümler. \\
\hline
\end{tabular}

Tablo 13. "Code.org platformunu kullanırken karşılaştığın problemler nelerdir? Bu problemlerle nasıl başa çıktın? Bu problemler öğrenme isteğinde olumsuz yönde etkili oldular mı?”

\begin{tabular}{|c|c|c|}
\hline Kategoriler & $f$ & Örnek Alıntılar \\
\hline Yardım alma & 9 & Ö1 Zorlandı̆̆ım zamanlarda arkadaşlarımdan yardım aldım. \\
\hline Olumsuzluğa kapılma & 8 & Ö1 Zorlandiğım zamanlarda canım sıkıld, olumsuz hissettim. \\
\hline Olumlu hissetme & 3 & $\begin{array}{l}\text { Ö6 Zorlandiğım zamanlarda pek olumsuz hissetmedim. } \\
\text { Ö6 Zorlandığım zamanlarda farklı şekillerde deneyerek devam } \\
\text { ettim. Başka şeyler de öğrenmiş oldum. }\end{array}$ \\
\hline İstek & 1 & Ö3 Biraz daha kolay olsa daha iyi olurdu. \\
\hline
\end{tabular}

*Bir öğrencinin birden fazla görüşü yer alabilmektedir.

Tablo 14. "Aynı uygulama bir kez daha yapılsa nelerin eklenmesini veya değiştirilmesini isterdin?"

\begin{tabular}{lll}
\hline Kategoriler & $\boldsymbol{f}$ & Örnek Alıntılar \\
\hline \multirow{2}{*}{ Zorluk } & Ö10 Bir bölümü geçerken zorlandiğımızda ekstra ipucu videoları olabilir. \\
& 3 & $\begin{array}{l}\text { Ö1 Bölümlerde hamle sınırı olmasa daha iyi olurdu. } \\
\text { Ö3 Bazı zor olan bölümler olmasa daha iyi olurdu. }\end{array}$ \\
\hline Anlaşlabilirlik & 2 & Ö11 Görüntülenen kodlar Türkçe olabilirdi. \\
\hline \multirow{2}{*}{ İstek } & 2 & $\begin{array}{l}\text { Ö1 Bölümlerde farklı karakterler olabilirdi (zombi - domuz vb. yerine). } \\
\text { Ö11 Code.org platformu Türkiye'ye ait olsa daha iyi olurdu. }\end{array}$ \\
\hline
\end{tabular}

*Bir öğrencinin birden fazla görüşü yer alabilmektedir.

Tablo 15. "Bu platform ile kodlama öğrenmeyi bir arkadaşına önerir misin? Neden?"

\begin{tabular}{|c|c|c|}
\hline Kategoriler & $f$ & Örnek Alıntılar \\
\hline Eğlenceli & 11 & $\begin{array}{l}\text { Ö11 Çünkü çok eğlenceli. } \\
\text { Ö6 Çünkü çok beğendim, çok güzel bir uygulama. }\end{array}$ \\
\hline Öğrenmeyi kolaylaştırıcı & 7 & $\begin{array}{l}\text { Ö5 Daha akılda kalıcı ögreniliyor. } \\
\text { Ö2 Daha kolay ögreniliyor. } \\
\text { Ö8 Daha hızlı ögreniliyor. } \\
\text { Ö6 Daha ögretici bir uygulama. }\end{array}$ \\
\hline
\end{tabular}


*Evet $(f=11)$.

*Bir öğrencinin birden fazla görüşü yer alabilmektedir.

Tablo 16. "Kodlama ile kendi oyununu kendin yazmak ister miydin? Sence bunu başarabilir misin?"

\begin{tabular}{lll}
\hline Kategoriler & $\boldsymbol{f}$ & Örnek Alıntılar \\
\hline Çalışma & 10 & $\begin{array}{l}\text { Ö11 Çok çalışırsam kendi oyunumu oluşturabilirim. } \\
\text { Ö8 Zor, çalışsam bile başaramayabilirim. }\end{array}$ \\
\hline Yardım alma & 1 & Ö2 Yardım alarak kendi oyunumu oluşturabilirim. \\
\hline
\end{tabular}

*Evet $(f=11)$.

*Bir ögrencinin birden fazla görüşü yer alabilmektedir.

Tablo 17. "Kodlama alanında merak ettiğin konular neler? Açıklar mısın?"

\begin{tabular}{lll}
\hline Kategoriler & $\boldsymbol{f}$ & Örnek Alıntılar \\
\hline & & $\begin{array}{l}\text { Ö6 Kodlama her yerde ögretiliyor mu? (Yurtiçi-yurtdışı) } \\
\text { Ö1 Kodlama nereden yapıllyor? }\end{array}$ \\
Merak edilenler & 7 & Ö8 Oynadı̆̆gmı bilgisayar oyunları nasıl yapıllyor? \\
& & Ö10 Niye Türkçe dili kullanılmıyor?
\end{tabular}

*Bir öğrencinin birden fazla görüşü yer alabilmektedir.

Tablo 18. "Kodlama ile ilgili bir iş alanında çalışmak ister miydin? Açıklar mısın?"

\begin{tabular}{|c|c|c|}
\hline Kategoriler & $f$ & Örnek Alıntılar \\
\hline Eğlenceli & 11 & $\begin{array}{l}\text { Ö3 Çünkü sevdim, güzel ve eğlenceliydi. } \\
\text { Ö5 Kendi oluşturduğum oyunu sunmak güzel olurdu. } \\
\text { Ö2 Başkalarına ögretebilmek güzel olurdu. } \\
\text { Ö6 Bazı değişikliklerle çocuklar için kodlamayı } \\
\text { daha ilgi çekici hâle getirebilirdim. }\end{array}$ \\
\hline Kazançli & 2 & Ö1 Bu şekilde çok para kazanılabilir. \\
\hline
\end{tabular}

Tablo 19. "Code.org platformunu kullanarak kodlama öğrenme sürecin, BTY dersi ile ilgili düşüncelerin değiştirdi mi? Değiştirdiyse olumlu mu olumsuz yönde mi? Örnek verebilir misin?”

\begin{tabular}{lll}
\hline Kategoriler & $\boldsymbol{f}$ & Örnek Alıntılar \\
\hline & & Ö5 Bilişim Teknolojileri dersini artı daha çok seviyorum. \\
& Daha zevkli, eğlenceli ve güzel geçiyor dersler. \\
Beğeni & $15 \quad$ Ö8 Daha fazla bilgisayar kullanabiliyoruz. \\
& & Ö1 Daha fazla Bilisim Teknolojileri dersi işlemek istiyorum. \\
& Ö9 Ders daha hizlı bitiyor gibi geliyor.
\end{tabular}

*Bir öğrencinin birden fazla görüşü yer alabilmektedir.

Tablo 20. "Eklemek istediğin herhangi bir şey var mı?"

\begin{tabular}{lll}
\hline Kategoriler & $\boldsymbol{f}$ & Örnek Alıntılar \\
\hline \multirow{2}{*}{ Beğeni } & 2 & $\begin{array}{l}\text { Ö4 Code.org'u çok beğendim. } \\
\text { Ö9 Her okulda kullanılmalt. }\end{array}$ \\
\hline
\end{tabular}

*Evet $(f=2)$ 


\section{TARTIŞMA, SONUÇ VE ÖNERILER}

\subsection{Code.org Platformunun 6. Sınıf Öğrencilerinin Programlama Öğrenim Düzeylerine Etkisi}

- Deney ve kontrol grubunda yer alan öğrencilerin uygulama öncesi programlama öğrenim düzeylerinin (PÖDA Ön Test) farklı olmadığı sonucuna ulaşılmıştır.

- BTY dersi çerçeve programındaki "Problem Çözme ve Programlama" ünitesi; deney grubuyla Code.org platformu desteği ile kontrol grubuyla ise normal öğretim yöntemleri ile işlenmiştir. Ardından gerçekleştirilen ölçme sonucunu (PÖDA Son Test) ön test sonuçları ile karşılaştırıldığında ise her iki grubun öğrenim düzeyinde de anlamlı bir artışın olduğu gözlenmiştir.

- Ayrıca araştırma probleminin tespiti için yapılan grup karşılaştırmasında deney grubu lehine anlamlı bir fark gözlenmiștir. Bu durumda Code.org platformunun programlama öğretiminde kullanılmasının normal yöntemlere göre başarılı olduğu sonucuna ulaşılmıştır. Genel olarak görsel programlama ortamlarının öğrencilerin programlama öğrenim düzeylerine etkisini içeren araştırmalar incelendiğinde alanyazındaki çalışmalarla bu araştırmanın benzer sonuçlara ulaştığı görülmektedir (Demir, 2015; Dinçer, 2018; Kayabaş1, 2016; Osman ve diğerleri, 2012; Solmaz, 2014; Şimşek, 2018; Yıldırım, 2016; Yiğit, 2016; Yüksel, 2017). Bu sonuçlar dikkate alınarak programlama öğretiminin Code.org platformu ile gerçekleştirilmesinin programlama öğrenim düzeyleri üzerinde daha etkili olduğu sonucuna ulaşılabilir. Alanyazında programlama eğitimi sürecinde oyunlaştırmanın öğrencilerin programlama öğrenim düzeyleri üzerinde etkili olabileceğini ifade eden çalışmalar da yer almaktadır (Alan, 2017; Yıldırım, 2016; Yue ve Wan, 2015; Yükseltürk ve Altıo, 2016). Code.org platformunun da programlama öğrenim düzeyini olumlu yönde etkilemesinde, yapısının hareketli ve oyun temelli olmasının etkili olduğu gösterilebilir. Derslerde çoklu ortam araçlarının kullanımına dair alanyazında yer alan çalışmalarda, öğrenci başarısının arttığ 1 ifade edilmiştir (Yaman, 2005). Code.org platformunun başarılı olması da bu sonuçla örtüşmektedir. Ayrıca bilgi işlemsel düşünme becerilerinin alt boyutlarından biri olan problem çözme becerilerinin programlama öğrenimi üzerinde etkisi dikkate alındığında görsel programlama platformu olan Code.org platformunun da bilgi işlemsel düşünme becerisini olumlu yönde etkilediği, bilgi işlemsel düşünme becerilerinin yüksek olmasının programlama öğrenim düzeyini geliştirmiş olabileceği söylenebilir (Çankaya ve diğerleri, 2017; Dizman, 2018; Erdem, 2018; Oluk ve diğerleri, 2018; Ozoran ve diğerleri, 2012; Özcan ve diğerleri, 2017; Vatansever, 2018). Gorman ve Bourne'in (1983) araştırmasında programlama öğretiminin öğrencilerin kural öğrenimine katkısı (Akpınar ve Altun, 2014); Durak ve Samur'un (2018) araştırmasında da programlama öğretim uygulamalarının hayat boyu öğrenme yeterliklerinin geliştirilmesine olumlu etkisi ifade edilmektedir. Buradan hareketle Code.org platformunun kural öğrenimine ve hayat boyu öğrenme becerisine katkısından bahsedilebilir.

\subsection{Code.org Platformunun 6. Sınıf Öğrencilerinin Programlama Öğrenimlerinin Kalıcılık Düzeylerine Etkisi}

- Programlama öğretiminden beş hafta sonra gerçekleştiren ölçümdeki sonuçları (PÖDA İzleme) PÖDA son test sonuçları kontrol altına alınarak karşılaştırıldığında anlamlı bir farklılaşma gözlenmiş, Code.org platformunun, öğrencilerin programlama öğrenimlerinin kalıcılığında normal yöntemlere nazaran daha etkili olduğu sonucuna ulaşılmıştır. Alanyazında Code.org platformunun programlama öğreniminin kalıcılık düzeyine etkisini içeren bir çalışmaya rastlanılmamıştır. Genel olarak görsel programlama ortamlarının programlama öğreniminin kalıcılık düzeyine etkisini içeren araştırmalar incelendiğinde ise alanyazındaki çalışmaların bu araştırma sonucunu 
desteklediği görülmektedir (Yıldırım, 2016; Yüksel, 2017). Bu bulgudan yola çıkılarak programlama öğretiminin Code.org platformu ile gerçekleştirilmesinin programlama öğreniminin kalıcılık düzeyi üzerinde daha etkili olduğu sonucuna ulaşılabilir. Ayrıca platformun oyun teması üzerine kurulu olduğu düşünüldüğünde bu durumun da kalıcılığa olumlu etki ettiği görüşü savunulabilir (Kılınçpınar, 2014; Koka, 2018; MEGEP, 2007; Savaş, 2014; Yıldırım, 2015).

\subsection{Code.org Platformunun Deney ve Kontrol Grubunda Yer Alan Öğrencilerin Ebodköy Tutumlarına Etkisi}

- Deney ve kontrol grubunda yer alan öğrencilerin uygulama öncesi tutum oranlarının (EBODKÖYTÖ Ön Test) farklı olmadığı sonucuna varılmıştır.

- Uygulamanın ardından gerçekleştirilen ölçme sonuçlarını (EBODKÖYTÖ Son Test) ön test sonuçlarıyla karşılaştırıldığında ise kontrol grubunda anlamlı bir değişime rastlanılmazken deney grubunda anlamlı bir farka rastlanılmış, öğrencilerde olumlu yönde değişiklik gözlenmiştir.

- Ayrıca araştırma probleminin tespiti için yapılan grup karşılaştırmasında deney grubu lehine anlamlı bir farklılık tespit edilmiştir. $\mathrm{Bu}$ durumda Code.org platformunun EBODKÖY tutumlarına normal yöntemlere nazaran daha olumlu etkiler meydana getirdiği kanısına varılmıştır. Bu kanı alanyazındaki Code.org platformunun kullanıldığ 1 deneysel çalışmalarca desteklenmektedir (Patan, 2016; Yıldız, 2018). Ayrıca diğer görsel programlama ortamlarının öğrencilerin tutumlarına etkisini içeren araştırmalar incelendiğinde ise benzer şekilde alanyazındaki çalışmalarla bu araştırma sonucu paralellik göstermektedir (Alan, 2017; Dinçer, 2018; Genç ve Karakuş, 2011; Ozoran ve diğerleri, 2012; Saygıner, 2017; Yıldırım, 2016). Bu sonuçlar dikkate alınarak programlama öğretiminin Code.org platformu ile gerçekleştirilmesinin öğrencilerin tutumları üzerinde daha etkili olduğu sonucuna ulaşılabilir. Alanyazında programlama eğitimi sürecinde oyunlaştırmanın öğrencilerin tutumları üzerinde etkili olabileceğini ifade eden çalışmalar da yer almaktadır (Alan, 2017; Yıldırım, 2016; Yükseltürk ve Altıok, 2016). Code.org platformunun da tutumu olumlu yönde etkilemesinde, yapısının hareketli ve oyun temelli olmasının etkili olduğu gösterilebilir.

\subsection{Deney Gurubu Öğrencilerinin Code.org Platformuna Yönelik Görüşleri}

- Deney grubu öğrencilerinin uygulama sonrası platforma yönelik görüşleri incelenmiştir. Öğrencilerin tamamı Code.org platformunun öğrenmelerini olumlu olarak etkilediğini ifade etmiştir. Öğrencilerin çoğunluğu görüşlerini açıklarken platformun görselliğini ve kendilerinin kullanmasını ön plana almışlardır. $\mathrm{Bu}$ sonuç, öğrencilerin bilgisayar destekli öğrenme ortamlarında daha başarılı olabileceğini ifade eden (Akpınar, 2006; Gürbulak, 2013; Kamacı ve Durukan, 2012; Kapucu, 2018; Karabulutlu, 2018) araştırma sonuçlarıyla benzerlik göstermektedir.

- Öğrencilerin tamamı Code.org platformunun öğrenmelerini daha kalıcı hâle getirdiklerini bildirmiştir. Buna gerekçe olarak da yüksek oranla görerek ve yaparak öğrenebilmelerini göstermişlerdir. Bu sonucu araçlarla desteklenen bir öğretimin normal yöntemlerin yer aldığ 1 ortamlara nazaran daha etkili olduğu ve öğrenmenin kalıcılığı açısından çok önemli olduğunu belirten (Alan ve Taşdemir, 2016; Korkmaz, 1997) araştırma sonuçlarının desteklediği görülmektedir.

- Öğrenciler Code.org platformunu beğendiklerini dile getirirken platformun öğrencilere kendi hesaplarını kullanabilme, öğrenmelerini takip edebilme gibi olanaklar sunması öne çıkan taraflar olmuştur. Ayrıca sürecin eğlenceli olması, aşamalı ilerlemesi, çeşitli bölümleri içermesi belirtilen diğer görüşlerdendir. Görsel programlama ortamları ile programlama öğretiminin, öğrenme ortamının eğlenceli olmasına katkı sağladığına (Lopez, Gonzalez ve Cano, 2016) yönelik çalışmalar vardır. Code.org platformu da bu çerçevede değerlendirilebilir. 
- Öğrencilerin tamamına yakını süreç içerisinde karşılaştıkları problem olarak platformun bazı bölümlerde zorlandıklarını ifade etmişlerdir. Bu durumda yüksek oranda olumsuz hisse kapıldıklarını, bu durumla arkadaşlarından yardım alarak başa çıktıklarını belirtmişlerdir. $\mathrm{Bu}$ sonuç görsel programlama ortamlarının sınıf içi etkileşimini artırdığını (Maloney ve diğerleri, 2010) ve işbirlikli çalışmayı olumlu yönde etkilediğini (Taylor ve diğerleri, 2010) ifade eden araştırmaların sonuçlarıyla paralellik gösterdiği söylenebilir.

- Öğretimin tekrarlanması hâlinde istenen değişiklikler konulu maddede öğrenciler yüksek oranda bir değişiklik istemediklerini iletmişlerdir. Kodlama dilinin Türkçe olması, zorlanılan bölümlerin yer almaması gibi istekler de dile getirilmiştir.

- Öğrencilerin tamamı Code.org platformu ile kodlama öğrenimini başkalarına tavsiye edebileceklerini belirtmişlerdir. Bu görüşlerine gerekçe olarak ise platformun çok güzel olmasını, öğretimi daha eğlenceli, daha akılda kalıcı, daha kolay, daha öğretici ve daha hızlı hâle getirmesini göstermişlerdir. Bu sonuç görsel programlama ortamları ile programlama öğreniminin kolay olduğunu ve programlama öğrenim düzeyini arttırdığ 1 (Genç ve Karakuş, 2011; Maloney ve diğerleri, 2010; Özcan ve diğerleri, 2017) sonucuna ulaşan araştırmaların sonuçlarıyla benzerlik gösterdiği söylenebilir.

- Öğrencilerin tamamı kodlama ile kendi oyunlarını oluşturmayı istediklerini belirtmişlerdir. Öğrencilerin tamamına yakını bu isteklerini çok çalışmaları hâlinde gerçekleştirebileceklerini ifade etmişlerdir. Görsel programlama ortamlarının öğrencilerin programlamaya karşı olan isteklerini arttırdığına değinen çalışmalarla bu açıdan bir benzerlik göze çarpmaktadır (Gülbahar ve Kalelioğlu, 2014; Kobsiripat, 2015).

- Öğrenciler kodlama alanında genel olarak merak ettikleri bir şey olmadığını söylemişlerdir. $\mathrm{Bu}$ öğretimin her yerde (yurtiçi-yurtdışı) gerçekleştirilme durumu, oyunların nereden, nasıl yapıldığı, dilin Türkçe olmaması merak edilen konular olarak ifade edilmiştir.

- Öğrencilerin çoğunluğu kodlamayla ilgili bir iş alanında çalışmak istediklerini belirtmiş, bu isteklerine gerekçe olarak da kodlamayı sevmelerini, güzel ve eğlenceli bulmalarını göstermişlerdir. Görsel programlama ortamlarının öğrencilerin programlamaya karşı olan isteklerini arttırdığı sonucuna ulaşan çalışmalar bu sonucu desteklemektedir (Gülbahar ve Kalelioğlu, 2014; Kobsiripat, 2015).

- Öğrencilerin tamamı Code.org platformunun BTY dersine karşı olan tutumlarını olumlu yönde değiştirdiğini; dersi artık daha çok sevdiklerini, dersin daha güzel, daha zevkli ve daha eğlenceli bir hal aldığını ifade etmişlerdir. Bu sonuç da görsel programlama ortamlarının öğrencilerin tutumlarını olumlu etkilediğini belirten araştırmalarca desteklenmektedir (Alan ve Taşdemir, 2017; Alan, 2017; Aslan, 2014; Dinçer, 2018; Fowler, 2012; Genç ve Karakuş, 2011; Ozoran ve diğerleri, 2012; Patan, 2016; Saygıner, 2017; Y1ldırım, 2016; Y1ldı, 2018).

- Ayrıca Code.org platformunun çok beğenilmesi ve her okulda kullanılmasının gerekliliği, tekrarlanan ve eklenen görüşlerdendir.

\section{5. Öneriler}

\subsubsection{Uygulayıcılara yönelik öneriler}

- BTY dersi müfredatında yer alan programlama öğretiminde Code.org platformundan yararlanılabilir.

- Eğitmenler Code.org platformundaki kurs planlamalarını öğrencileri için aşamalılık ilkesi çerçevesinde basitten karmaşığa doğru yapabilir.

- $\mathrm{Bu}$ araştırmada olduğu gibi kurs öncesi platformun tanıtımı (kullanımı, kapsamı, takip mekanizması, çevrimiçi yapısı, sertifikasyon ödülü vb.) yapılabilir. 
- Süreç içerisinde işbirlikli öğrenmeye yönelik öğrenciler arası grup çalışmalarına (akran öğretimi, ikili denetim, karşıllklı sorgulama vb. yöntemler) yer verilebilir.

- Eğitim çerçevesinde harmanlanmış (hibrid-karışık-karma) öğrenme ortamlarına ilişkin metotlara yer verilebilir.

- Süreç içerisinde konuya ilişkin problemlerin çözümüne dair kontrollü rekabet ortamları (farklı yollarla çözebilme, hızlı çözebilme vb.) oluşturulabilir.

\subsubsection{Araştırmacılara yönelik öneriler}

- Var olan çalışmalar incelendiğinde, Code.org platformuna ilişkin veya bu platformu içeren çalışmaların sayısının az olduğu görülmüştür. Bu alanda daha fazla deneysel çalışmalar yapılabilir.

- Code.org platformu ile programlama eğitimi gerçekleştiren eğitmenlere yönelik deneysel çalışmalar yapılabilir.

- $\mathrm{Bu}$ araştırma 6. sınıf öğrencileri ile gerçekleştirilmiştir. Aynı çalışma farklı sınıf düzeylerindeki öğrencilere de uygulanarak genişletilebilir.

- Farklı sosyoekonomik özelliklere sahip daha geniş örneklemler üzerinde çalışmalar yapilabilir.

- Code.org platformunun ilkokul kademesindeki durumuna yönelik sınıf öğretmenleri ile araştırmalar yapılabilir.

\subsection{3 İlgili kurumlara yönelik öneriler}

- Code.org platformu üzerinden programlama eğitimini yürütecek eğitim kurumları, teknolojik materyallerini ve laboratuvarlarını amaca uygun olarak düzenlenmelidir. Code.org platformu üzerinden programlama eğitimini yürütecek eğitim kurumları, teknolojik materyallerini ve laboratuvarlarını amaca uygun olarak düzenlenmelidir.

- MEB, BTY dersi başta olmak üzere ilgili müfredatlarını Code.org platformunun derslerde kullanılabilmesi için doğrudan uyumlu hâle getirebilir.

- Eğitim Fakültelerindeki ilgili öğretmen adayları programlama eğitimine yönelik Code.org platformunu içeren uygulamalı çalışmalara tabi tutulabilir.

\section{KAYNAKÇA}

Akpınar, E. (2006). Fen öğretiminde soyut kavramların yapılandırılmasında bilgisayar desteği: Yaşamımızı yönlendiren elektrik ünitesi. Dokuz Eylül Üniversitesi, İzmir, Erişim adresi: https://dspace.deu.edu.tr/xmlui/handle/12345/6913.

Akpınar, Y. ve Altun, A. (2014). Bilgi toplumu okullarında programlama eğitimi gereksinimi. Ilkögretim Online, 13(1).

Alan, D. ve Taşdemir, Ş. (2016). An Example Study For Teachıng Algorıthm Structure Usıng Games In Computer Sciences, International Conference on Education in Mathematics, Science \& Technology (ICEMST), Bodrum/Türkiye.

Alan, D. (2017). Dijital oyun tabanl yaklaşım ile yazılım geliştirme öğretimi (Yayınlanmamış yüksek lisans tezi). Selçuk Üniversitesi Fen Bilimleri Enstitüsü: Konya (No:467392).

Aslan, Ü. (2014). Olasılık Öğreniminin Oyun Programlama Yöntemiyle Geliştirilmesi (Yayınlanmamış yüksek lisans tezi). Boğaziçi Üniversitesi Fen Bilimleri Enstitüsü: İstanbul (No:356973).

Aytekin, A., Çakır, F.S., Yücel, Y.B. ve Kulaözü, İ. (2018). Geleceğe Yön Veren Kodlama Bilimi ve Kodlama Öğrenmede Kullanılabilecek Bazı Yöntemler. Avrasya Sosyal ve Ekonomi Araştırmaları Dergisi, 5(5), 24-41. 
Cevahir, H. ve Özdemir, M. (2017). Programlama öğretiminde karşılaşılan zorluklara yönelik öğretmen görüşleri ve çözüm önerileri. Conference: 11. Uluslararası Bilgisayar ve Ögretim Teknolojileri Ĕ̆itimi Sempozyumu sunulan bildiri. İnönü Üniversitesi, Malatya. Erişim adresi: http://icits2017.inonu.edu.tr/dosya/1493636695061912000.pdf.

Çankaya, S., Durak, G. ve Yünkül, E. (2017). Robotlarla programlama eğitimi: öğrencilerin deneyimlerinin ve görüşlerinin incelenmesi. Turkish Online Journal of Qualitative Inquiry, $8(4), 428-445$.

Çatlak, Ş., Tekdal, M. ve Baz, F.Ç. (2015). Scratch Yazılımı İle Programlama Öğretiminin Durumu: Bir Doküman İnceleme Çalışması. Journal of Instructional Technologies ve Teacher Education, 4(3).

Demir, F. (2015). Programlama ögretiminde eğitsel programlama dilinin farklı kullanımlarının programlama başarısı ve kaygısına etkisi (Yayınlanmamış doktora tezi). Atatürk Üniversitesi Eğitim Bilimleri Enstitüsü: Erzurum (No:429631).

Demirer, V. ve Sak, N. (2016). Dünyada ve Türkiye'de programlama eğitimi ve yeni yaklaşımlar. Eğitimde Kuram ve Uygulama, 12(3), 521-546.

Dinçer, A. (2018). 6.sınıf ögrencilerine scratch ve kodu game lab programlama dillerinin ögretiminde ögrencilerin tutum, öz yeterlilik ve akademik başarılarının karşılaştırılması (Yayınlanmamış yüksek lisans tezi). Dokuz Eylül Üniversitesi Eğitim Bilimleri Enstitüsü: İzmir (No:512965).

Dizman, A. (2018). Kodlama, robotik, 3D tasarım ve oyun tasarımı eğitiminin 11-14 yaş grubu ögrencilerinin problem çözme becerileri ve üstbilişsel farkındalık düzeyine etkisi (Yayınlanmamış yüksek lisans tezi). Bahçeşehir Üniversitesi Eğitim Bilimleri Enstitüsü: İstanbul (No:523935).

Durak, H.Y. ve Samur, Y. (2018). Kodlama Eğitiminin Öğretmen Adaylarının Yaşam Boyu Öğrenme Yeterliliklerinin Geliştirmesine Katkısının İncelenmesi. Ege Eğitim Teknolojileri Dergisi, 2(2) 55-67.

Erdem, E. (2018). Blok tabanl ortamlarda programlama ögretimi sürecinde farklı ögretim stratejilerinin çeşitli değişkenler açısından incelenmesi (Yayınlanmamış yüksek lisans tezi). Başkent Üniversitesi Eğitim Bilimleri Enstitüsü: Ankara (No:509354).

Erekmekçi, M. ve Fidan, Ş. (2012). Oyunun Tasarım Platformları: Oyunun Eğitim ve Kültüre Etkisi. Journal of Life Sciences, 1(1). Erişim adresi: http://www.yasambilimleridergisi.com/makale/pdf/1356289798.pdf, Erişim Tarihi: 19.12.2016.

Fessakis, G., Gouli, E. ve Mavroudi, E. (2013). Problem solving by 5-6 years old kindergarten children in a computer programming environment: A case study. Computers \& Education, 63, 87-97.

Fowler, A. (2012, Kasim). Enriching student learning programming through using Kodu. 3rd Annual Conference of Computing and Information Technology Research and Education New Zealand (CITRENZ2012)'da sunulan bildiri. Christchurch, New Zealand. Erişim adresi: http://www.citrenz.ac.nz/conferences/2012/pdf/2012CITRENZ_Fowler01Kodu.pdf.

Genç, Z. ve Karakuş, S. (2011). Tasarımla Öğrenme: Eğitsel Bilgisayar Oyunları Tasarımında Scratch Kullanımı. $5^{\text {th }}$ International Computer \& Instructional Technologies Symposium (ICITS). Elazığ, Türkiye.

Gorman Jr, H. ve Bourne Jr, L.E. (1983). Learning to think by learning LOGO: Rule learning in third-grade computer programmers. Bulletin of the Psychonomic Society, 21(3), 165-167. 
Gülbahar, Y. ve Kalelioğlu, F. (2014). The effects of teaching programming via Scratch on problem solving skills: A discussion from learners ${ }^{\text {ee }}$ perspective. Informatics in EducationAn International Journal, 13(1), 33-50.

Gürbulak, N. (2013), Okul Öncesi Öğrencilerine Renk Kavramını Kazandırmada Geçerli ve Yeterli Bir Ĕgitsel Yazılım Geliştirme ve Ölçme Çalışması (Yayınlanmamış yüksek lisans tezi). Bahçeşehir Üniversitesi Fen Bilimleri Enstitüsü: İstanbul (No:341262).

Kamac1, E. ve Durukan, E. (2012). Araştırma Görevlilerinin Eğitimde Tablet Bilgisayar Kullanımına İlişkin Görüşleri Üzerine Nitel Bir Araştırma (Trabzon Örneği), Uluslararası Türkçe Edebiyat Kültür Eğitim Dergisi, 3203-215.

Kapucu, T. (2018). Bilgisayar destekli eğitimin 8. sinı öğrencilerinin permütasyon-kombinasyonolasılık başarısına ve ögrencilerin bilgisayar destekli ĕgitime ilişkin tutumlarına etkisi (Yayınlanmamış yüksek lisans tezi). Orta Doğu Teknik Üniversitesi Eğitim Bilimleri Enstitüsü: Ankara (No:463551).

Karabulutlu, L. (2018). Okul öncesi fen eğitiminde analojilerin ve bilgisayar destekli eğitimin akademik başarı açısından değerlendirilmesi (Yayınlanmamış yüksek lisans tezi). Kafkas Üniversitesi Eğitim Bilimleri Enstitüsü: Kars (No:519638).

Karataş, E. (2014). Eğitimde Oyunlaştırma: Araştırma Eğilimleri. Ahi Evran Üniversitesi Kırşehir Eğitim Fakültesi Dergisi, 15(2), 315-333.

Kayabaş1, E. (2016). Öğretmen adaylarının alice deneyimi: 3 b ortamda programlama (Yayınlanmamış yüksek lisans tezi). Uludağ Üniversitesi Eğitim Bilimleri Enstitüsü: Bursa (No:429742).

Keçeci, G., Alan, B. \& Zengin, F. K. (2016). Eğitsel Bilgisayar Oyunları Destekli Kodlama Öğrenimine Yönelik Tutum Ölçeği: Geçerlilik ve Güvenirlik Çalışması. Education sciences, 11(4), 184-194.

Kılınçpınar, $\quad$ P. (2014). Erişim adresi: http://pelinkilincpinar.blogspot.com/2014_09_01_archive.html, Yaz1 tarihi: 02.09.2014, Erişim tarihi: 16.01.2019.

Kobsiripat, W. (2015). Effects of the media to promote the scratch programming capabilities creativity of elementary school students. Procedia-Social and Behavioral Sciences, 174, 227-232. Erişim adresi: https://www.sciencedirect.com/science/article/pii/S1877042815007028?via\%3Dihub.

Koka, V. (2018). Sosyal bilgiler dersinde kullanılan bilgisayar destekli eğitsel oyunların ögrencilerin ders başarısına olan etkisi (Yayınlanmamış yüksek lisans tezi). İnönü Üniversitesi Eğitim Bilimleri Enstitüsü: Malatya (No:505026).

Korkmaz, H. (1997). İlkokul fen ögrretiminde araç-gereç kullanımı labaratuvar uygulamaları açısından ögrretmen yeterlikleri (Yayınlanmamış yüksek lisans tezi). Hacettepe Üniversitesi Eğitim Bilimleri Enstitüsü: Ankara (No:63847).

Küçükoğlu, Ö. (2014). 21.yüzyll becerileri için en etkin oluşumlar: "Kod okur-yazarllğg” ve "FLL”. Erişim adresi: https://www.weebly.com/, Erişim Tarihi:14.09.2015.

Lopez, J.M., Gonzalez, M.R. ve Cano, E.V. (2016). Visual programming languages integrated across the curriculum in elementary school: A two year case study using "Scratch" in five schools. Computers \& Educations, 97, 129-141. Erişim adresi: https://www.sciencedirect.com/science/article/pii/S0360131516300549?via\%3Dihub.

Maloney, J., Resnick, M., Rusk, N., Silverman, B. ve Eastmond, E. (2010). The Scratch programming language and environment. Trans. Comput. Educ., 10(4), 1-15. Erişim adresi: https://ieeexplore.ieee.org/document/6504380. 
MEGEP (2007). Çocuk Gelişimi ve Eğitimi, Oyun Etkinliği - I. Ankara.

Oluk, A., Korkmaz, Ö. ve Oluk, H.A. (2018). Scratch'ın 5. Sınıf Öğrencilerinin Algoritma Geliştirme ve Bilgisayarca Düşünme Becerilerine Etkisi. Turkish Journal of Computer and Mathematics Education (TURCOMAT), 1-1.

Onuncu Kalkınma Planı (2014-2018), Türkiye Cumhuriyeti Kalkınma Bakanlığı, Erişim adresi: http://www.kalkinma.gov.tr/Lists/Kalknma\%20Planlar/Attachments/12Onuncu_Kalkınm a_Planı.pdf, Erişim Tarihi: 10 Haziran 2018.

Osman, M.A., Zakaria, M.N., Loke, S.P. ve Downe, A.G. (2012, Aral1k). Secondary students' perfectionism and their response to different programming learning tools. Paper presented at the Humanities, Science and Engineering (CHUSER). 2012 IEEE Colloquium on sunulan bildiri. Kota Kinabalu, Malezya. Erişim adresi: https://ieeexplore.ieee.org/document/6504380.

Ozoran, D., Çağıltay, N. ve Topallı, D. (2012). Using Scratch In Introduction to Programming Course for Engineering Students. In 2nd International Engineering Education Conference (IEEC2012), (pp. 125-132).

Özcan, S., Ergün, K., Köse, Ö., Emir, N. ve Gezgin, D. (2017). Bilgisayar Programlama Eğitiminde Scratch Programı Kullanımına İlişkin Lise Öğrencilerinin Görüşleri. 2nd International Scientific Researches Congress on Humanities and Social Sciences (IBAD2017), İstanbul.

Özmen, B. ve Altun, A. (2014). Undergraduate Students' Experiences in Programming: Difficulties and Obstacles. Turkish Online Journal of Qualitative Inquiry, 5(3), 9-27.

Patan, B. (2016). Okul öncesi kodlama öğretim programının geliştirilmesi (Yayınlanmamış yüksek lisans tezi). Bahçeşehir Üniversitesi Eğitim Bilimleri Enstitüsü: İstanbul (No:436081).

Ramadhan, H.A. (2000). Programming by discovery. Journal of Computer Assisted Learning, 16, 83-93.

Resnick, M., Maloney, J., Hernandez, A., Easmond, E., Brennan, K., Millner, A., Rosenbaum, E., Silver, J., Silverman, B. ve Kafai, Y. (2009). Scratch: programming for all. Communications of the ACM, 52(11), 60-67. Erişim adresi: https://dl.acm.org/citation.cfm?doid=1592761.1592779.

Savaş, E. (2014). Oyunla Öğretim Yöntemi Uygulamasının Başarı ve Kalıcılık Üzerindeki Etkisi (Deneysel Bir Çalışma) (Yayınlanmamış yüksek lisans tezi). Onsekiz Mart Üniversitesi Eğitim Bilimleri Enstitüsü: Çanakkale (No:356358).

Saygıner, Ş. (2017). Blok tabanlı görsel ve metin tabanlı programlama ögrretimlerinin erişi, mantıksal düsünme ve motivasyona etkileri (Yayınlanmamış yüksek lisans tezi). Hacettepe Üniversitesi Eğitim Bilimleri Enstitüsü: Ankara (No:454912).

Sayın, Z. ve Seferoğlu, S.S. (2016). Yeni Bir 21. Yüzyıl Becerisi Olarak Kodlama Eğitimi ve Kodlamanın Eğitim Politikalarına Etkisi. Akademik Bilişim 2016, Adnan Menderes Üniversitesi, Aydın.

Solmaz, E. (2014). Programlama dili öğretiminde Alice yazılımının ders başarısı, eleştirel düşünme ve problem çözme becerileri ile üstbilişsel farkındalık düzeyine etkisi (Yayınlanmamış doktora tezi). Gazi Üniversitesi Eğitim Bilimleri Enstitüsü: Ankara (No:381475).

Şimşek, E. (2018). Programlama öğretiminde robotik ve scratch uygulamalarının ögrrencilerin bilgi işlemsel düsünme becerileri ve akademik başarılarına etkisi (Yayınlanmamış yüksek 
lisans tezi). Ondokuz Mayıs Üniversitesi Eğitim Bilimleri Enstitüsü: Samsun (No:519321).

Taşdemir, Ş. ve Şüyun, S. B. (2016). Bilgisayar Oyun Tasarımı ve Eğitsellik Kazandırılmasına Yönelik Bir Yaklaşım. Selçuk-Teknik Dergisi, 15(2), 113-124.

Taylor, M., Harlow, A. ve Forret, M. (2010). Using a computer programming environment and an interactive whiteboard to investigate some mathematical thinking. Procedia-Social and Behavioral Sciences, $8, \quad 561-570 . \quad$ Erişim adresi: https://linkinghub.elsevier.com/retrieve/pii/S187704281002183X.

Utting, I., Cooper, S., Kölling, M., Maloney, J. \& Resnick, M. (2010). Alice, greenfoot, and scratch--a discussion. ACM Transactions on Computing Education (TOCE), 10(4), 17.

Vatansever, Ö. (2018). Scratch Ile Programlama Öğretiminin Ortaokul 5. ve 6. Sinıf Öğrencilerinin Problem Çözme Becerisi Üzerindeki Etkisinin İncelenmesi (Yayınlanmamış yüksek lisans tezi). Uludağ Üniversitesi Eğitim Bilimleri Enstitüsü: Bursa (No:501053).

Wing, J.M. (2006). Computational thinking. Communications of the ACM, 49(3), 33-35.

Yaman, M. (2005). Solunum Zinciri Konusunda Simülasyonla Desteklenmiş Bir Bilgisayar Programının Öğrenme ve İlgiye Etkisi. Hacettepe Üniversitesi Ĕ̆itim Fakültesi Dergisi, $29,222-228$.

Yıldırım, B. (2015). Eğitsel Oyun ve Dönüt-Düzeltmenin Öğrenme Düzeyi ve Kalıcılı̆̆a Etkisi (Yayınlanmamış yüksek lisans tezi). Necmettin Erbakan Üniversitesi Eğitim Bilimleri Enstitüsü: Konya (No:407553).

Yıldırım, E. (2016). Dijital oyun tasarım programlarının eğitimde önemi. Mesleki Bilimler Dergisi, 5 (2), 12 - 19. Erişim adresi: http://dergipark.gov.tr/mbd/issue/34074/377099.

Yıldız, M. (2018). Oyunlaştırılmış blok tabanlı algoritmik düşünme etkinliklerinin öğrencilerin programlamaya yönelik tutum, katılım ve becerilerine etkisi (Yayınlanmamış yüksek lisans tezi). Atatürk Üniversitesi Eğitim Bilimleri Enstitüsü: Erzurum (No:513250).

Yiğit, F.M. (2016). Görsel programlama ortamı ile öğretimin ögrencilerin bilgisayar programlamayı öğrenmesine ve programlamaya karşı tutumlarına etkisinin incelenmesi (Yayınlanmamış yüksek lisans tezi). Ondokuz Mayıs Üniversitesi Eğitim Bilimleri Enstitüsü: Samsun (No:442990).

Yue, W.S. ve Wan, W.L. (2015). The Effectiveness of Digital Game for Introductory Programming Concepts. The $10^{\text {th }}$ International Conference for Internet Technology and Secured Transactions (ICITST-2015), Erişim adresi: $\mathrm{http} / /$ ieeexplore.ieee.org/stamp/stamp.jsp?tp=\&arnumber=7412134\&tag=1, Erişim Tarihi: 05.04.2016.

Yükseltürk, E. ve Altık, S. (2016). Investigation of pre-service information technology teachers' game projects prepared with Scratch. SDU International Journal of Educational Studies, 3(1), 59-66. Erişim adresi: http://dergipark.gov.tr/sduijes/issue/20865/223885.

Yüksel, S. (2017). Scratch programı ögretiminde ayrılıp birleşme tekniği kullanımının ögrencilerin derse yönelik tutumuna, akademik başarısına ve kalıcılı̆̆a etkisi (Yayınlanmamış yüksek lisans tezi). Adnan Menderes Üniversitesi Eğitim Bilimleri Enstitüsü: Aydın (No:472231). 


\section{EXTENDED ABSTRACT}

Today, the expression of educated human being used for people who can read and write and have arithmetic knowledge has been affected by the rapid changes. Basic skills aimed by education; Coding skill, which is the common language of digital culture and enables students to plan their own futures, has also been added (EBA, 2019). As the main purpose of the Turkish Education System, the Tenth Development Plan includes the expressions of "individuals who have developed the ability to think, perceive, solve problems, use science and technology, and have the basic knowledge and skills necessary for information societies, and can produce" (Tenth Development Plan 2014 ). In the information age we are in, coding education is an important tool in line with this goal (Aytekin et al., 2018). It has become very important to provide students with opportunities in this regard from an early age. Therefore, the preparation of the necessary learning tools at the basic education level will eliminate an important deficiency and a solid support pillar will be provided for programming teaching (Akpinar \& Altun, 2014).

Industrializing countries have adopted the view of the necessity of learning programming in order to be more ready and effective to move to Industry 4.0, which is the new industrial revolution (Aytekin et al., 2018), and included compulsory courses for this area in their curricula (Demirer \& Sak, 2016; Sayın and Seferoğlu, 2016). In order to teach programming better, which is stated to be a difficult process as well as being necessary, it was stated that visual programming applications should be used, but it was realized that they were not used at a sufficient level in our country (Solmaz, 2014). These tools, which provide students with an opportunity to design scenarios, provide a free environment, and embody this process with animations (Ramadhan, 2000), thus transforming it into a more interesting environment (Utting, Cooper, Kölling, Maloney, \& Resnick, 2010), provide students with codes and rules. It saves you from memorizing, syntax mistakes, and getting bogged down in lines of code.

Code.org platform, one of the visual programming applications; It was established within the scope of the project initiated to spread programming learning with the support of the world's most famous programmers and founders of major technology companies such as Microsoft, Facebook, Twitter and Google. This platform is suitable for educational activities due to its structure, and its availability for teachers and students is similar to the school structure. During the process, the teacher can follow the students through the system, and make the necessary interventions regarding the relevant course. In addition to the teacher, students can also monitor their own progress, thus facilitating time and space.

The lack of studies on the effect of Code.org platform on students' programming education levels and attitudes in the literature increases the importance of this research, and it is thought that this study will provide resource diversity for researchers who want to work on the subject. In addition, regarding the teaching of programming subject; With the features of the Code.org platform, Information Technologies and Software course is expected to help instructors by guiding educators in programming teaching. Considering the need for coding instruction and the features of the Code.org platform, the aim of this research is to investigate the effects of the Code.org platform on the 6th grade students 'attitudes towards programming and their programming learning, and to examine the students' views on this platform. determined as.

The research was conducted with 22 students studying at a secondary school affiliated to the Ministry of National Education in Gediz district of Kütahya. In this study, Attitude Scale for Educational Computer Games Supported Coding Learning developed by Keçeci, Alan and Zengin (2016), Semi-Structured Interview Form for Code.org Platform and Programming Learning Leveling Tool were used as data collecting tools. In the research carried out in accordance with the experimental research design, 2 X 3 (experimental - control X pre-test - post-test - retentiontest) model from the real trial models was used. At the beginning of the application, data collecting tools were applied to two groups, and then students participated in programming in two different ways as usual methods and Code.org platform supported methods. After the end of the 
experimental process, the post-test measurements were taken from the groups and the interview form was applied to the experimental group. Five weeks after the completion of the experimental procedure, retention-test measurements were taken for the permanence of programming learning. The results of the interview form were interpreted descriptively with the content analysis. The data obtained from the other measurement processes were evaluated by using Mann Whitney U test, Wilcoxon Signed Ranks test, covariance analysis (ANCOVA) and Bonferroni paired comparisons test and SPSS statistical package program.

As a result of the research, it was found that Code.org platform had more positive effects on students' programming learning and retention of programming learning than usual teaching methods. In addition, the Code.org platform positively increased the students' attitudes towards educational computer games supported coding learning. As a result of the conducted semistructured interviews, it was revealed that this platform had a more positive effect on students' achievement; students enjoyed more of the learning process and developed more positive attitudes towards the Information Technology and Software course. Considering the process and results of the study; it is recommended to integrate the Code.org platform into learning environments and to be done new research to expand the experimental studies in this area. 